Revue bibliographique pour le domaine irano-aryen

\title{
Marek Olbrycht. "Augustus versus Phraates IV. Some Remarks on the Parthian-Roman Relations"
}

\section{Leonardo Gregoratti}

\section{(2) OpenEdition \\ 1 Journals}

\section{Electronic version}

URL: http://journals.openedition.org/abstractairanica/49704

DOI: 10.4000/abstractairanica.49704

ISBN: 1961-960X

ISSN: 1961-960X

Publisher:

CNRS (UMR 7528 Mondes iraniens et indiens), Éditions de l'IFRI

Electronic reference

Leonardo Gregoratti, "Marek Olbrycht. "Augustus versus Phraates IV. Some Remarks on the ParthianRoman Relations"', Abstracta Iranica [Online], Volume 40-41 | 2019, document 37, Online since 30 October 2019, connection on 24 April 2021. URL: http://journals.openedition.org/abstractairanica/ 49704 ; DOI: https://doi.org/10.4000/abstractairanica.49704

This text was automatically generated on 24 April 2021.

Tous droits réservés 


\title{
Marek Olbrycht. "Augustus versus Phraates IV. Some Remarks on the Parthian-Roman Relations"
}

\author{
Leonardo Gregoratti
}

\section{REFERENCES}

Marek Olbrycht. "Augustus versus Phraates IV. Some Remarks on the Parthian-Roman Relations” in K. Ruffing, K. Droß-Krüpe (eds.). Emas non quod opus est, sed quod necesse est Beiträge zur Wirtschafts-, Sozial-, Rezeptions- und Wissenschaftsgeschichte der Antike Festschrift für Hans-Joachim Drexhage zum 70. Geburtstag. Wiesbaden:

Harrassowitz Verlag, 2018, p. 389-397

1 In this short contribution M.O. takes into consideration the historical role of Musa, the slave-concubine donated by Augustus to the Parthian king Phraates IV, who rapidly gained the favour of the king and became the only queen, after giving birth to a son. A few years later, all the other princes, born from other wives were sent to Rome with their families as hostages. Olbrycht does not think as many scholars in the past that this event was caused only by Musas' influence on Phraates and by her will of clearing the way to the throne for his son. It is possible in fact, that Phraates decided intentionally to eliminate from the scene all the many Arsacid princes that could be used against him or his chosen heir by the emerging powerful Parthian noble families. The ancient accounts like the one on the $6^{\text {th }}$ book of Strabo, who mentions Parthia's weakness were probably draft a long time after the events when the negative consequences of that ill-fated decision were aggravating Parthian instability. 


\section{AUTHORS}

\section{LEONARDO GREGORATTI}

Durham University 